\title{
REDESAIN MATA PISAU ALAT PENCACAH BONGGOL JAGUNG
}

\author{
Dayuwanto Harun $^{1)}$, Romi Djafar ${ }^{2)}$, Agus Susanto Ginting ${ }^{2)}$ \\ ${ }^{1)}$ Mahasiswa Politeknik Gorontalo, Kampus Puncak Desa Panggulo Bone Bolango \\ ${ }^{2)}$ Tim Pengajar pada Program Studi Mesin dan Peralatan Pertanian, Politeknik Gorontalo
}

\begin{abstract}
ABSTRAK
Bongkol jagung merupakan salah satu limbah dari tanaman jagung yang tidak memiliki nilai ekonomi di Indonesia. Kandungan nutrisi bongkol jagung berdasarkan analisis di Laboratorium Ilmu Makanan Ternak meliputi kadar air, bahan kering, protein kasar dan serat kasar berturut-turut sebagai berikut 29,54; 70,45; 2,67 dan 46,52\% dalam 100\% bahan kering. Bongkol jagung sangat potensial untuk dapat dikembangkan sebagai pakan ruminansia. Namun untuk pengolahannya dibutuhkan suatu mesin yang bisa menghancurkan bongkol jagung kering ini hingga menjadi partikel kecil berukuran $1 \mathrm{~mm}$ atau krang dari $1 \mathrm{~mm}$ untuk pakan ternak atau bahan campuran pakan ternak. Untuk itu, dengan berkembangnya ilmu pengetahuan dan teknologi, perlu diciptakan inovasi untuk meningkatkan nilai ekonomis dan pemanfaatannya sebagai pakan ternak. "Redasin Mata Pisau Alat Pencacah Bonggol Jagung" dengan Kapasitas 23,11gr/jam sebagai Pakan Ternak" dimaksudkan untuk membantu para peternak, agar bisa memanfaatkan limbah bongkol jagung kering untuk pakan ternak. Setelah dilakukan perancangan mesin pencacah bonggol jagung, diperoleh dimensi dan ukuran mesin yang sesuai dengan standar yang ada, seperti daya motor penggerak yang digunakan, diameter poros yang digunakan, ukuran pulley dan jenis sabuk yang digunakan, serta komponen-komponen mesin lainnya. Sehingga akan dihasilkan mesin pencacah bonggol jagung dengan biaya yang lebih efisien dan terjangkau dan hasil produksinya juga sesuai dengan yang diharapkan.
\end{abstract}

Kata kunci : Alat pencacah, Bonggol Jagung, Redesain

\section{REDESIGN EYE KNIFE TOOLS CORN BALL}

\begin{abstract}
Corn hump is one of the waste from corn that has no economic value in Indonesia. Corn-chopped nutritional content based on analysis at the Laboratory of Animal Food Science includes water content, dry matter, crude protein and crude fiber respectively as follows 29.54; 70.45; 2.67 and $46.52 \%$ in 100\% dry ingredients. Corn humps are very potential to be developed as ruminant feed. However, for processing it requires a machine that can destroy this dry corn hump to become a small particle measuring $1 \mathrm{~mm}$ or less from $1 \mathrm{~mm}$ for animal feed or a mixture of animal feed ingredients. For this reason, with the development of science and technology, innovations need to be created to increase economic value and its use as animal feed. "Redesign of Corn Knife Bonggol Counter Tool" with a Capacity of 23,11gr / hour as Animal Feed "is intended to help farmers, so they can use dry corn hump waste for animal feed. After the design of the corncob counter is done, the dimensions and size of the machine are in accordance with the existing standards. Such the driving motor power used, shaft diameter used, pulley size and type of belt used, and other engine components. So that the corncob counter will be produced with a more efficient and affordable cost and the production results are also as expected.
\end{abstract}

Key words : Counter tool, Corn Bump, Redesign 


\section{PENDAHULUAN}

Bonggol jagung banyak digunakan terutama untuk penggemukan sapi, dengan komposisi sebanyak $20 \%$ dari seluruh pakan yang diberikan. Jika seluruh pakan sapi sebanyak 7,5 kg/ekor/hari maka komposisi $20 \%$ menjadi $1,5 \mathrm{~kg} /$ ekor/hari. Jika dalam 1 ha tanaman jagung dihasilkan 2.748 $\mathrm{kg}$ bonggol jagung, dengan pemberian $1,5 \mathrm{~kg}$ bonggol jagung/ekor/hari yang akan dapat memenuhi kebutuhan sapi sebanyak 5,02 ekor/tahun

Bonggol jagung berbentuk batang berukuran cukup besar, sehingga tidak dapat dikonsumsi ternak jika diberikan langsung, oleh karena itu, untuk memberikannya perlu penggilingan terlebih dahulu. Untuk membantu kebutuhan akan pakan ternak sapi yang cukup tinggi, maka penulis tertarik untuk melakukan redesain sebuah alat yaitu " Redesain Mata Pisau Alat Pencacah Bonggol Jagung"

\section{TINJAUAN PUSTAKA}

Bonggol jagung adalah limbah yang diperoleh ketika biji jagung dirontokkan dari buahnya. Kandungan nutrisi bongkol jagung berdasarkan analisis di Laboratorium Ilmu Makanan Ternak meliputi kadar air, bahan kering, protein kasar dan serat kasar berturut-turut sebagai berikut $29,54 \% ; 70,45 \% ; 2,67 \%$ dan $46,52 \%$ dalam $100 \%$ bahan kering.

Faktor utama penentu keberhasilan dalam usaha peternakan adalah penyediaan pakan. Salah satu penyediaan pakan bagi ternak ruminansia adalah dengan pemanfaatan pakan asal sisa hasil pertanian, perkebunan maupun agroindustri. Salah satu sisa tanaman pangan dan perkebunan yang mempunyai potensi cukup besar adalah jagung. Apabila limbah yang banyak tersebut tidak dimanfaatkan, maka akan memicu terjadinya pencemaran lingkungan. Pencemaran lingkungan merupakan masalah bersama, yang semakin penting untuk diselesaikan, karena menyangkut keselamatan, kesehatan dan kehidupan skrang ini. Siapapun bisa berperan serta dalam menyelesaikan masalah pencemaran lingkungan ini, termasuk diri sendiri. Dimulai dari lingkungan yang terkecil, yaitu diri sendiri, sampai ke lingkungan yang lebih luas. Untuk itu, agar pencemaran limbah dapat diminima lisir perlu adanya pemanfaatan limbah agar mempunyai daya guna. (R. Zulkarnain, S. Slamet, 2014).

\section{METODE PENELITIAN}

Penelitian ini dilaksanakan pada bulan Juni 2018-Agustus 2017, bertempat di Laboratorium Mesin Umum dan Laboratorium Las Politeknik Gorontalo.

\section{Rancangan Alat}

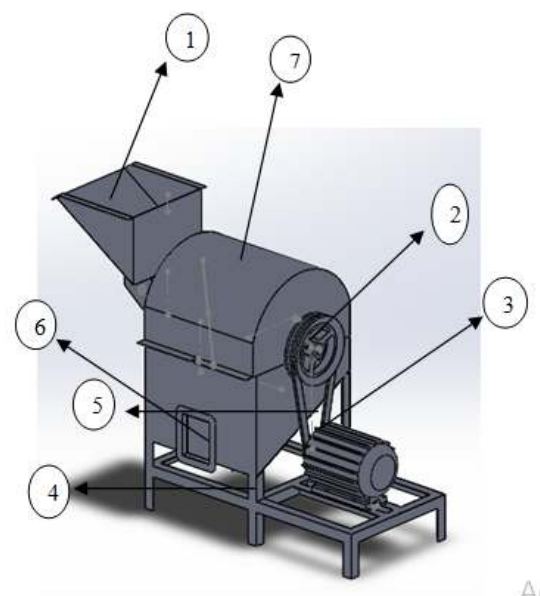

Gambar 1. Desain Alat Pencacah Bonggol Jagung

Keterangan :

1.Hopper input

2.Pully

3. Motor listrik

4. Kaki mesin

5.V-belt

6. Hopper output

7. Cover Body

\section{Bagian-bagian alat}

a. Mata pisau

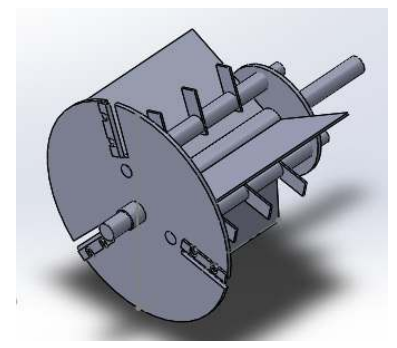

Gambar 2. Desain Mata pisau

Menunjukkan bahwa rangkaian komponen mata pisau terdiri dari dari beberapa subsistem. Diantaranya pelat sebagai dudukan pisau, poros yang akan diputar oleh motor penggerak, plat yang akan mengurai tumpukan bonggol jagung didalam 
ruang pencacahan. Mata pisau berfungsi untuk memcacah bong jagung yang masih berukuran panjang.

\section{b. Cave body}

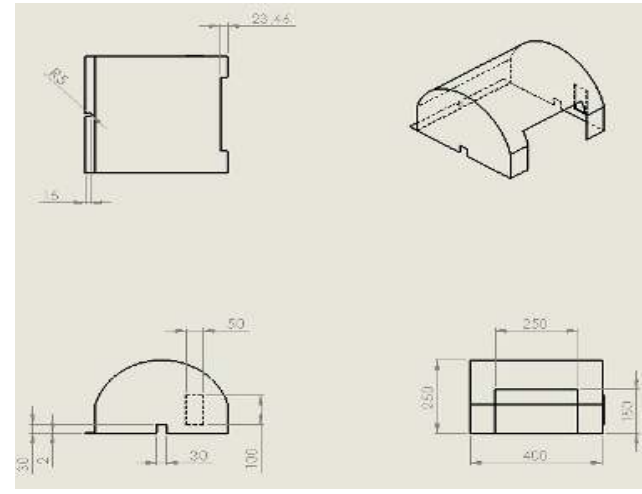

Gambar 3. Caver Body

Cover body menggunakan bahan plat esel dengan ketebalan $2 \mathrm{~mm}$ berfungsi untuk menahan bonggol jagung agar tidak keluar pada saaat proses pencacahan berlangsung.

\section{c. Hopper Input}

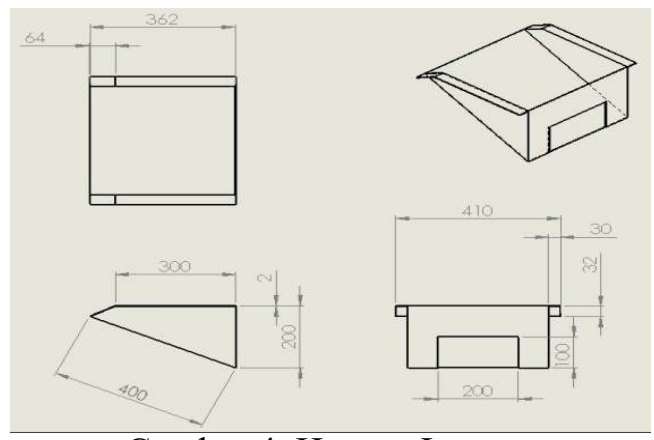

Gambar 4. Hopper Input

Hopper Input menggunakan bahan plat esel dengan ketebalan $2 \mathrm{~mm}$ berfungsi sebagai inputnya bonggol jagung pada proses pencacahan.

d. Rangka mesin

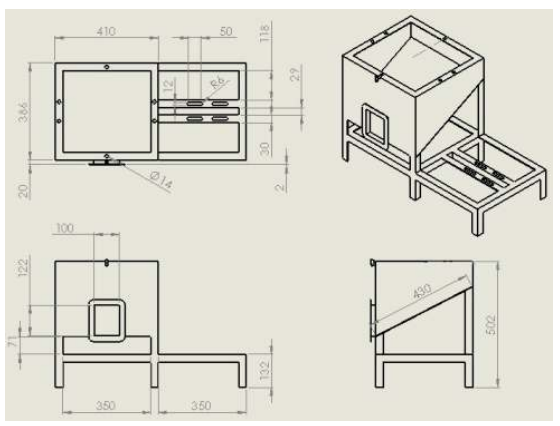

Gambar 5. Rangka Mesin
Rangka mesin menggunakan besi siku ynag berfungsi sebagai dudukan body, motor penggerak,dan pisau pencacah.

\section{e. Saringan}

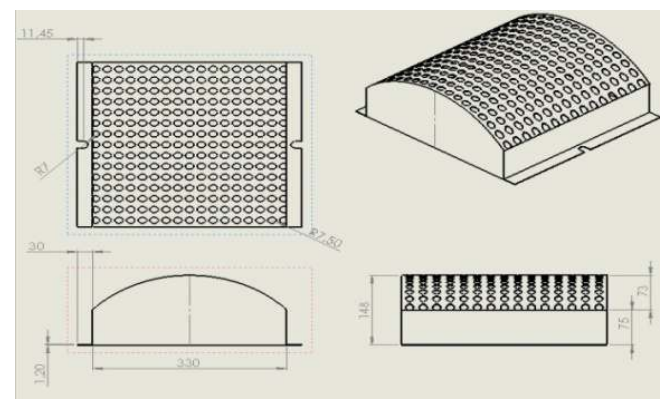

Gambar 6. Saringan

Saringan berfungsi sebagai pemisah antara bonggol jagung yang halus dan kasar.

\section{HASIL DAN PEMBAHASAN}

Aplikasi Proses pembuatan alat pencacah bonggol jagung dapat di bagi menjadi 2 bagian yaitu pengerjaan pada mesin produksi,dan mesin las. Pengerjaan pada mesin produksi seperti membubut poros, membuat lubang pada bushing penahan mata pisau pencacah bonggol jagung, membuat alur spie, adapun pengerjaan pada mesin las yaitu mengelas rangka mesin, mengelas hopper input, mengelas Cover body yang berbentuk kubah. Salah satu parameter yang penting diperhatikan dalam proses pembuatan komponen pada proses produksi adalah kecepatan mesin bubut. Pada pembuatan alat pencacah bonggol jagung terdapat pengerjaan pada mesin bubut yaitu pembuatan busing mata pisau dengan diameter $3 / 4$ inci. Sehingga secara matematis kecepatan mesin bubut dapat ditentukan menggunakan persamaan sebagai berikut.

$$
N=\frac{35 \mathrm{~m} / \text { menit } x 1000}{3.14 \times 19 \mathrm{~mm}}=\frac{35000}{59.66}
$$

$$
N=586 R p m
$$

(Sularso K., 2002)

Keterangan :

- Nilai Vc sebesar $35 \mathrm{~m} / \mathrm{menit}$ adalah nilai baja ST 37

- Nilai 1000 konversi m ke millimeter

Putaran mesin bubut yang digunakan untuk pembubutan busing sebesar $586 \mathrm{Rpm}$. 
Selanjutnya pengerjaaan pengelasan untuk bagian-bagian utama dari alat pencacah bonggol jagung yang dapat dibagi beberapa tahap sebagai berikut.

\section{Rangka Utama.}

Rangka utama merupakan bagian yang terpenting dari alat pencacah bonggol jagung karena pada komponen ini menjadi tumpuan dari beberapa komponen lainnya seperti Hoper input, output, dan cover body. Tahapan pengerjaan bagian-bagiannya sebagai berikut.

\section{Pembuatan rangka mesin}

Rangka mesin dibuat menggunakan besi siku berukuran 40 x $40 \mathrm{~mm}$ dengan ketebalan $2 \mathrm{~mm}$ berbahan dasar besi ST 37. Rangka mesin berfungsi sebagai penopang semua rangkaian komponen Mesin penghancur bonggol jagung. Seperti cover body bonggol jagung, mata pisau pencacah bonggol jagung, blower atau kipas, saringan pacacah bonggol jagung serta dudukan untuk peletakan motor penggerak mesin pencacah bonggol jagung. Dan rangka mesin memiliki dimensi panjang keseluruhan lebar $38,5 \mathrm{~cm}$, panjang $41 \mathrm{~cm}$ tinggi $100 \mathrm{~cm}$. Gambar 7 menunjukkan komponen itu dari alat pencacah bonggol jagung.

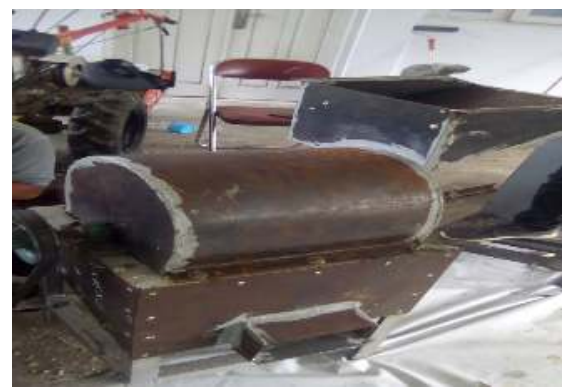

Gambar 7. Rangkaian Alat Pencacah Bonggol Jagung

Berdasarkan Gambar 7 menunjukkan bahwa terdapat beberapa komponen yang sudah dirangkai menjadi satu kesatuan dengan komponen lainya. Untuk lebih jelasnya bagian dalam dari alat tersebut dapat ditunjukkan pada Gambar 8 sebagai berikut:

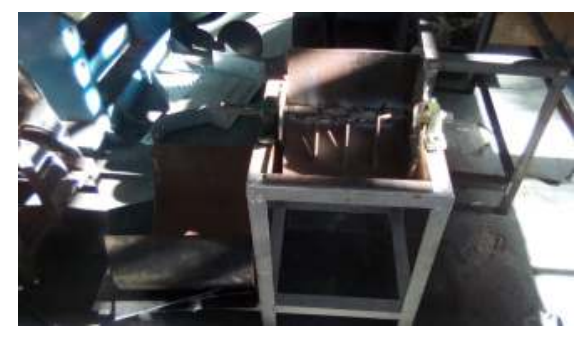

Gambar 8. Bukan Alat Pencacah Bonggol Jagung

Gambar 8 menunjukan bahwa rangakaian dalam alat pencacah bonggol jagung terdapat mata pisau pemotong bonggol jagung, pisau pencacah bonggol jagung, dan kipas bonggol jagung.

2. Caver body pencacah bonggol jagung

Caver body pencacah bonggol jagung dibuat menggunakan plat esell dengan tebal 2 $\mathrm{mm}$. Caver body ini berfungsi sebagai penutup pada saat proses pencacahan bonggol jagung berlangsung, tahap pembuatanya dari proses pemotongan plat menggunakan batu gerinda potong dengan menggambar garis pada permukaan plat menggunakan penitik dan mistar baja untuk membantu meluruskan garis yang akan di gambar pada permukaan plat. Caver body pencacah bonggol jagung memiliki dimensi panjang $73 \mathrm{~cm}$, tinggi $30 \mathrm{~cm}$, lebar $33 \mathrm{~cm}$. Setelah plat sudah selesai di potong selanjutya plat tersebut dibentuk menjadi stengah lingkaran menggunakan mesin roll, selanjutnya tekuk kedua sisi plat yang sudah di roll menggunakan alat penekuk plat dengan lebar sisi plat yang akan ditekuk.

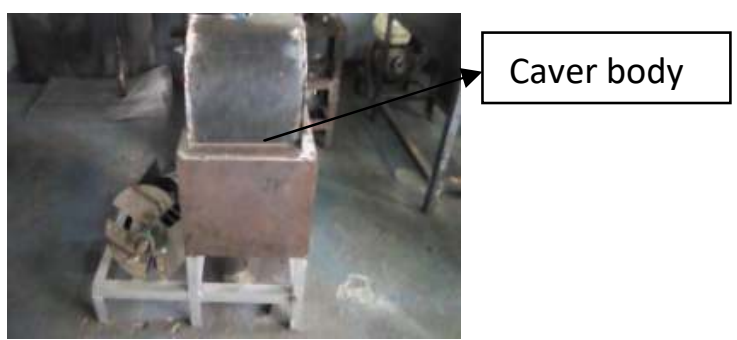

Gambar 9. Caver Body Dari Alat Pencacah Bonggol Jagung

Gambar 9 menunjukan caver body yang menutupi mata pisau alat pencacah bonggol jagung.

3. Saringan pencacah bonggol jagung 
Saringan terbuat dari besi plat esell dengan tebal $2 \mathrm{~mm}$ yang berfungsi sebagai penyaring untuk memisahkan cacahan bonggol jagung yang sudah halus dan yang masih kasar dimensi panjang penyaring $54 \mathrm{~cm}$, lebar $33 \mathrm{~cm}$, tinggi $30,4 \mathrm{~cm}$. penyaring ini dilubangi dengan mata bor , setiap lubang berukuran 7 mm,dengan jarak antara lubang satu dengan yang lainya $1 \mathrm{~mm}$. Tahap pertama pembuatan saringan yaitu melukis permukaan plat menggunakan penitik untuk membuat garis dan mistar baja untuk membantu meluruskan garis yang akan dibuat. Setelah itu potong plat yang sudah memiliki ukuran menggunakan batu gerinda potong. Selanjutnya menggaris permukaan plat lagi untuk membuat lubang saringan dengan jarak setiap garis 50x50 mm, berikutnya membuat lubang di setiap pertemuan garis yang telah dibuat menggunakan mesin frais untuk membuat lubang tersebut dengan mata bor $\varnothing 7 \mathrm{~mm}$, setelah lubang jadi tahap selanjutnya membentuk plat mnjadi steengah lingkaran menggunakan mesin roll dan menekuk kedua sisi plat dengan lebar yang akan ditekuk $40 \mathrm{~mm}$, gunakan penitik $\varnothing 7 \mathrm{~mm}$ untuk memperbesar lubang penyaring sehingga mempercepat jatuhnya bonggol jagung ke hopper.

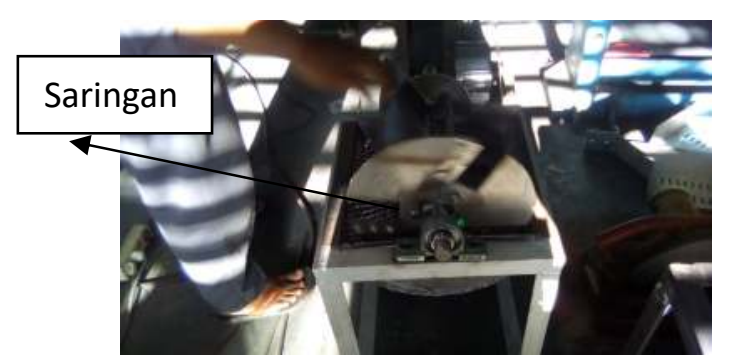

Gambar 10. Saringan Pencacah Bonggol Jagung

Gambar 10. menunjukan saringan sebagai pemisah antara bonggol jagung yang halus dan kasar, ukuran lubang pada saringan $7 \mathrm{~mm}$.

\section{HopPer input}

Hopper input terbuat plat esell dengan tebal $2 \mathrm{~mm}$ yang berfingsi sebagai tempat masuknya bonggol jagung yang akan dicacah.

5. Pisau pemotong bonggol jagung

Pisau pemotong bonggol jagung terbuat dari besi stenliss steel dengan ketebalan $6 \mathrm{~mm}$ yang berbentuk lingkaran ,dimensi lingkaran tersebut berukuran 29,5 $\mathrm{cm}$. seperti yang di tunjukan pada gambar 4.5

6. Pisau pencacah bonggol jagung

Pisau pencacah bonggol jagung tebuat dari plat strip dengan ukuran $3 \times 3$. Dan berfungsi sebagai pengahalus bonggol jagung. Pisau pengahalus ini tediri dari Sembilan buah, setiap pisau memiliki panjang $15 \mathrm{~cm}$.

\section{Poros utama}

Poros utama tebuat dari besi baja dengan demensi 1 incih berfungsi sebagai penggerak semua kompenen-komponen pada poros utama, seperti pisau pemotong bonggol jagung, pisau pencacah bonggol jagung, dann kipas.

8. Kipas

Kipas terbuat dari plat esell dengan ketebalan $2 \mathrm{~mm}$, kipas berfungsi untuk mengipas bonggol jagung yang akan tercacah.

9. Bos penahan

Bos penanahan terbuat dari besi baja dengan dimensi $3 / 4$ incih yang berfungsi penahan mata pisau pencacah bonggol jagung.

\section{Proses Perakitan Alat}

Rangka mesin dibuat menggunakan besi siku berukuran 40x40mm dengan ketebalan $2 \mathrm{~mm}$ berbahan dasar besi ST 37. Rangka mesin berfungsi sebagai penopang semua rangkaian komponen Mesin penghancur bonggol jagung. Caver body penutup pencacah bonggol jagung dibuat menggunakan plat esell dengan tebal $2 \mathrm{~mm}$. Caver body ini berfungsi sebagai penutup pada saat proses pencacahan bonggol jagung berlangsung, Saringan terbuat dari besi plat esell dengan tebal 2 $\mathrm{mm}$ yang berfungsi sebagai penyaring untuk memisahkan cacahan bonggol jagung yang sudah halus dan yang masih kasar, pisau prmotong bonggol jagung ini terbuat dari bahan stenlis steel yang mempunyai ketebalan 6 mil, dengan berbentuk lingkaran dimensi lingkaran $29,5 \mathrm{~cm}$, pisau pencacah bonggol jagung tebuat dari plat strip dengan ukuran $3 \times 3 \mathrm{~mm}$. Dan berfungsi sebagai pengahalus bonggol jagung. Pisau pengahalus ini tediri dari Sembilan buah, setiap pisau memiliki panjang $15 \mathrm{~cm}$.

\section{Prosedur Pengujian Alat}

a) Persiapan 
Pada dasarnya pengujian ini hanya untuk mengetahui apakah alat yang dibuat sesuai dengan yang direncanakan dan mengetahui hasil dari pengujian alat apakah sesuai dengan yang direncanakan dan diharapkan.

Adapun langkah-langkah dalam proses pengujian alat pencacah bonggol jagung adalah:

1. Sediakan bonggol jagung untuk persiapan pengujian sebanyak $3 \mathrm{~kg}$.

2. Siapkan timbangan jarum untuk pengukuran massa bonggol jagung.

3. Lakukan pengukuran massa bongkol jagung sebesar $3 \mathrm{~kg}$ dan bagi masingmasing $1 \mathrm{~kg}$ untuk 3 kali pengujian.

4. Selanjutnya pengukuran kadar air menggunakan alat moisture digital.

5. Siapkan alat ukur waktu berupa stopwatch

6. Lakukan pengeringan bonggol jagung yang telah ditimbang dengan durasi waktu 1.,2., dan 3 jam terhadapap masing-masing massa bonggol jagung.

7. Setelah pengeringan sesuai dengan waktu yang ditentukan dilakukan penimbangan kembali untuk mengecek tingkat perubahan massa bonggol jagung tersebut.

8. Kemudian hidupkan mesin pencacah bonggol jagung

9. Masukan kedalam hopper pada mesin pencacah bonggol jagung secara teratur.

10. Pengujian dilakukan sebanyak tiga kali untuk melihat kapsitas kerja, keseragaman cacahan dan efesiensi alat yang telah dibuat.

b) Persiapan bahan baku

Bahan baku yang digunakan adalah bonggol jagung yang telah mengalami proses pengeringan dengan memeperhatikan parameter waktu untuk mengetahui kandungan kadar air. Gamabar 4.9 menunjukan proses pengeringan bonggol jagung. Dengan waktu yang berbeda di mulai dari pengeringan satu jam,dua jam dan tiga jam dengan massa bonggol jagung yang sma yaitu $1 \mathrm{~kg}$.

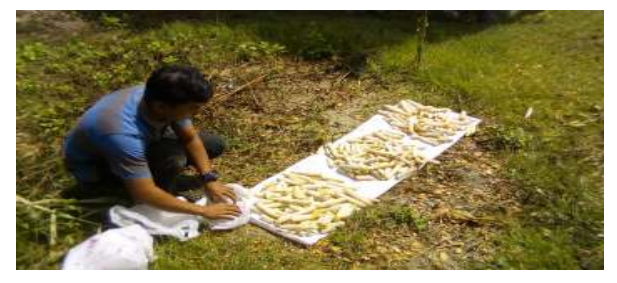

Gambar 11. Proses Pengeringan Bonggol Jagung
Gambar 11 menunjukan proses pengeringan bonggol jagung dengan waktu yang berbeda pengeringan ini bertujuan untuk dapat mengetahui kapasitas kerja mesin ,dan laju pencacahan. Adapun waktu pengeringan bonggol jagung mulai dari 1 jam, 2 jam, dan 3 jam dengan kandungan kadar air yang sama 19\%. Setelah melakukan pengeringan bonggol jagung akan dicacah dengan memperhatikan waktu selama pencacahan berlangsung, maka dari kapasitas pencacahan dapat ditentukan dengan melihat waktu yang lama pencacahan.

\section{Analisis Pengujian Kinerja Alat Pencacah Bonggol Jagung}

Pengujian kinerja alat dilakaukan untuk mengetahui seberapa besar kapasitas laju kerja dari yang diharapakan. pada penelitian ini. Analisis performa difokuskan pada dua hal yaitu kapasitas kerja mesin dan laju pencacahan.

a) Laju pencacahan berkaitan dengan rendemen yang dihasilkan. Rendemen adalah perbandingan antara bonggol jagung yang telah dicacah dengan yang akan dicacah. Rendemen diukur berdasarkan variable kadar air untuk setiap pengujian . kapasitas kerja mesin sebagai berikut:

- Kapasitas kerja mesin pencacahan selama pengeringan 1 jam.

$$
\begin{gathered}
K \sigma=\frac{600 \mathrm{gr}}{643^{3} \text { detil }} \\
K a=92 \mathrm{grjetk}
\end{gathered}
$$

- Kapasitas kerja mesin pencacah selama pengeringan 2 jam.

$$
\begin{aligned}
& \Lambda \sigma=\frac{500 \mathrm{gr}}{49,36 \text { detik }} \\
& K a=10,1296 \mathrm{gr} / \operatorname{det} \mathrm{k}
\end{aligned}
$$

- Kapasitas kerja mesin pencacah selama pengeringan 3 jam

$$
\begin{aligned}
K a & =\frac{400 \mathrm{gr}}{36.14 \text { detık }} \\
K a & =11,068 \mathrm{gr} / \mathrm{dett} k
\end{aligned}
$$

- Jadi nilai rata-rata dari kapasitas kerja mesin setelah melakukan pengujian sebanyak tiga kali adalah $=23,12$ gr/detik

b) Hubungan waktu pencacah terhadap cacahan bonggol jagung 
Kapasitas laju mesin diukur dari hasil cacahan (gram) terhadap waktu yang dibutuhkan (detik) dari hasil pengujian dapat ditunjukkan pada Gambar 12. sebagai berikut.

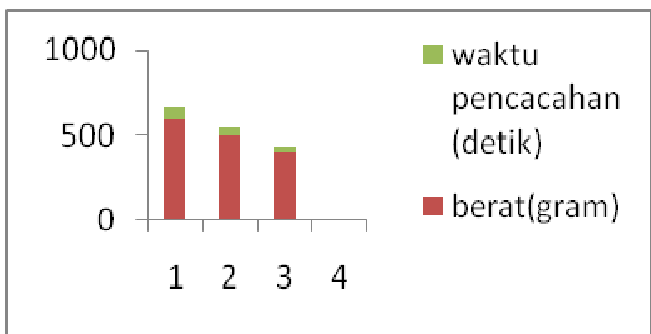

Gambar 12. Grafik Waktu Pencacahan Terhadap Cacahan Bonggol.

Tren grafik yang ditunjukkan pada Gambar 12 diketahui bahwa perubahan waktu pengeringan terhadap cacahan yang di dihasilkan. Berdasarkan tiga percobaan menunjukkan bahwa nilai tertinggi yaitu sebesar $11.06 \mathrm{gr} / \mathrm{jam}$ terjadi pengeringan yang tiga 3 jam yang memiliki kadar air 19\%. Sedangkan yang terendah terjadi pada hasil pengujian yang 1 jam dengan hasil cacahan 9.32 gr/jam dengan air yang sama. sehingga dapat disimpulkan bahawa semakin lama waktu pengeringan maka semakin cepat pencacahan bonggol jagung.

c) Rendemen yang dihasilkan

Uji Rendemen $=\frac{\text { Berat bahan yang telah dicacah }}{\text { Berat Bahan Yang akan dicacah }} \times 100 \%$

- Uji rendemen kapsitas kerja mesin dengan kadar air $19 \%$ setelah pengeringan selama 1 jam.

$$
=\frac{600 \mathrm{gr}}{1000 \mathrm{gr}} \times 100 \%=60 \%
$$

- Uji rendemen kapasitas kerja mesin dengan kadar air 19\% setelah pengeringan selama 2 jam.

$$
\frac{500 \mathrm{~g} r}{1000 \mathrm{~g} r} \times 100 \%=50 \%
$$

- Uji rendemen kapasitas kerja mesin dengan kadar air 19\% setelah pengeringan 3 jam.

$$
=\frac{400 g r}{1000 g r} \times 100 \%=40 \%
$$

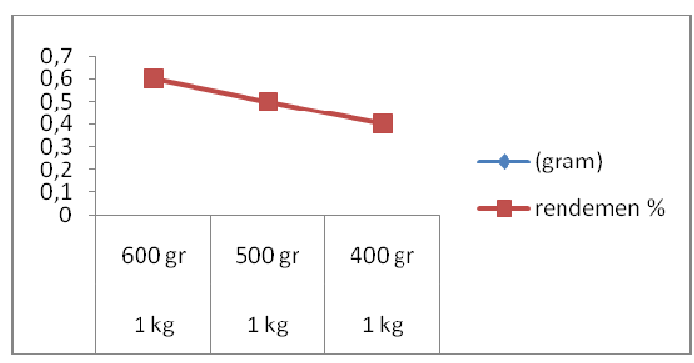

Gambar 13. Grafik Hasil Pengujian Rendemen

Gambar 13 menunjukan hasil pengujian rendemen dari massa bonggol jagung sebelum tercacah dan setelah tercacah, dapat dilihat dari grafik di atas bahwa hasil rendemen terendah adalah $40 \%$, dan hasil rendemen tertinggi adalah $60 \%$. Sehingga dapat disimpukan semakin kering bonggol jagung yang akan dicacah maka semakin sedikit cacahan yang dihasilkan hal itu terjadi karena penurunan sebesar $10 \%$.

d) Kapasitas laju pencacahan

1. Kapasitas Kerja Pencacahan

Kapasitas kerja alat dihitung dengan cara melakukan kerja (mencacah bahan) selama 1 jam kemudian menimbang bahan hasil cacahannya.

$$
\mathrm{Ka}=\frac{B K}{t}
$$

Keterangan :

$\mathrm{Ka}=$ Kapasitas pencacahan $(\mathrm{kg} / \mathrm{jam})$

$\mathrm{BK}=$ Berat hasil cacahan $(\mathrm{kg})$

$\mathrm{t}=$ waktu mencacah bahan $(1 \mathrm{jam})$

a. Kapasitas kerja mesin pencacahan selamapen geringan 1 jam.

$$
K a=\frac{600 \mathrm{gr}}{64.32 \text { det } i k}=9,328 \mathrm{gr} / \operatorname{detik}
$$

b. Kapasitas kerja mesin pencacah selama pengeringan 2 jam.

$$
K a=\frac{500 \mathrm{gr}}{49.36 \operatorname{det} i k}=10,1297 \mathrm{gr} / \operatorname{det} i k
$$

c. Kapasitas kerja mesin pencacah selama pengeringan 3 jam.

$$
K a=\frac{400 \mathrm{gr}}{36,14 \mathrm{d \theta tik}}=11,068 \mathrm{gr} / \mathrm{detik}
$$




\section{KESIMPULAN DAN SARAN}

\section{Kesimpulan}

Kesimpulan yang di dapatkan dari perancangan Mesin Pencacah Bonggol Jagung yaitu :

1. Perubahan waktu pengeringan terhadap cacahan yang di dihasilkan Berdasarkan dari tiga percobaan diperoleh nilai tertinggi yaitu sebesar $11.06 \mathrm{gr} / \mathrm{jam}$ terjadi pada pengeringan tiga 3 jam yang memiliki kadar air 19\%. Sedangkan yang terendah terjadi pada hasil pengujian yang 1 jam dengan hasil cacahan $9.32 \mathrm{gr} / \mathrm{jam}$ dengan air yang sama.

2. Hasil pengujian rendemen yang di ukur berdasarkan massa bonggol jagung sebelum tercacah dan setelah tercacah. Hasil pengujian adalah rendemen terendah sebesar $40 \%$, dan hasil rendemen tertinggi adalah $60 \%$.

3. Kiapasitas kerja mesin dapat mencacah sebesar 23,11 gr/jam

\section{Saran}

Dari hasil desain Mesin Pencacah Bonggol Jagung menunjukan proses pecacahan berjalan dengan baik, tetapi perlu adanya perbaikan pada jarak mata pisau pemotong dan hopper input. Adapun saran yang direkomendasikan untuk arah pengembangan kedepannya adalah:

1. Penggerak menggunakan moror bensin $5.5 \mathrm{PK}$

2. Jarak Pisau terhadap dinding pencacahan harus sesuai dengan ukuran bonggol jagung.

\section{DAFTAR PUSTAKA}

R. Zulkarnain, S. Slamet, and T. H. (2014).

Perancangan Mesin Hammer Mill Penghancur Bongkol Jagung dengan Kapasitas 100kg/Jam sebagai Pakan Ternak. Pros. SNATIF, (1), 79-84.

Sularso K., S. (2002). Dasar Perencanaan dan Pemilihan Elemen Mesin. PT.Pradnya Paramita. 